\title{
AN EPIDEMIOLOGICAL STUDY OF MENTAL RETARDATION \\ WITHOUT A COMMON GENETIC CAUSE, IN THE \\ POPULATION OF HIMACHAL PRADESH, INDIA
}

\section{THAKUR NEELAM \& VERMA SAVITRI}

Department of Biosciences, Himachal Pradesh University, City-Shimla, Country-India

\begin{abstract}
This study evaluated the contribution of potential risk factors of mental retardation without a common genetic cause of aware the population and delineate intercession methods. The present study included 150 MR of unrevealed causes and 150 normal children as a control for taking account of attribution of dysmorphic features, deformities, development deceleration, pedigrees of MR, delayed development, etc. For ascertaining the degree of mental retardation, Stanford-Binet Intelligence test was conducted for every patient and alienated into two categories i.e. Mild (IQ 70 to 50$55)$ and serious category (IQ<50-55). We abstracted information on demographic, prenatal, perinatal and neonatal risk factors of MR which was selected stringently based on recent literature. The parental age effect was not observed in mild MR but in severe mental retardation, risk augmented steadily and autonomously with increasing maternal age. Lack of maternal education, history of pregnancy loss, no consanguinity, birth at home, neonatal infections, lack of breast feeding, diarrhea were independently associated with mild congenital abnormality. Whereas, the prevalence of serious congenital abnormality was found to be concomitant with maternal illiteracy, consanguinity, multiple births, neonatal jaundice and lack of breast feeding. This work is uncovering the present situation and ascertains the utmost tenacious interventions to decrease the occurrence of childhood MR in Himachal Pradesh.
\end{abstract}

KEYWORDS: Paternal Age Effect, Maternal Age Effect, Economic Status, Late Birth Cry \& Neonatal Jaundice

Received: Aug 07, 2017; Accepted: Aug 27, 2017; Published: Oct 13, 2017; Paper Id.: IJEEFUSOCT20174

\section{INTRODUCTION}

Impact of MR on families and society is considerable due to its effect on quality of life and efficiency as a whole. IQ is not the solely means of measuring MR but adaptive behavior and systems of supports also need to be measured (AAMR, 1992). Standardized measures of intelligence become effective only when a child is older than 5 years because cases with mild mental retardation can only be ascertained when elementary education get started. According to an estimate, 3\% of children globally marked some degree of MR (McLaren and Bryson, 1987; Stevenson et al., 1996; Zeldin and Kao, 2012), even though estimates fluctuate with the demographic and socioeconomic composition of population's cohorts (Charara et al. 2017; Lakhan et al., 2015; Maulik et al. 2011), with definitions and investigation, design (McKenzie et al., 2016). As far as our knowledge, information regarding causes of non-genetic MR is scarce, so present study documented demographic, prenatal, perinatal and neonatal risk factors that might be direct causative elements or lie somewhere in the causal pathway. Our health system can be protected from this lifelong disability when these risk factors can be monitored stringently and burden of the society could be reduced. 


\section{METHODOLOGY}

\section{Subjects}

Participants of the present study were by design, 150 MR patients with non- genetic cause and 150 individuals as a control group with normal cognition. Every patient was individually attended by researcher and assessed for getting information by filling a proforma, which incorporated variables that selected a priori as potential risk factors, for mental retardation. Severity was classified according to Stanford-Binet test: 50-55 to 70 for mild, 35-40 to 50-55 for moderate, 2025 to 35-40 for severe and $<20-25$ for profound. In the present study moderate, severe and profound degrees were combined into a single category known as serious. All MR, mild and serious patients were further categorized into isolated and cases with other neurological abnormalities like epilepsy, microcephaly, visual impairments, hearing impairments for ascertaining the authentic association of risk factors with MR. All control subjects did not have any of neurological abnormalities incorporated in our delineation.

\section{Statistical Treatment}

To compute the weighted estimates of the prevalence of risk factors in MR, statistical techniques like frequency, percentage, mean were used. The chi - square test was performed to evaluate the association between MR and potential risk factors, $\mathrm{P}$ values below 0.05 were considered statistically significant.

\section{RESULTS}

This study cohort included 150 children attributed to MR of unknown etiology from various places of Himachal Pradesh with a mean age of 14.5 years (range: 10-17 years). Among all children with a diagnosis of MR of unknown cause, males outnumbered females by a ratio of 2.6:1.

\section{Isolated MR Cases}

Children with isolated MR was found to be associated with parental age (paternal age, maternal age), economic status, cohabitation with the male partner who drinks heavily, late birth cry and multiple births. Most of them had birth at home, suffered from jaundice in the infant stage and were not breast fed (Table 1).

\section{MR Cases with other Neurological Disorders}

This condition also showed the same association; like isolation, but certain differences were found, i.e no maternal age effect was noticed, most of them had delivery in hospital, had the history of high body temperature during pregnancy etc. (Table 1).

\section{Isolated Mild MR Cases}

It had same associations as are found in isolated MR cases except two factors, i.e. advanced maternal age and neonatal jaundice, which showed no significant relations (Table 2).

\section{Mild MR Cases with Other Neurological Disorders}

Similar associations were noticed as in mild isolated MR except some features like advanced maternal age effect was seen and had a history of high body temperature of the mother during gestation period. When compared with MR cases having other neurological disorders, no maternal age effect was found and history of first trimester bleeding was seen in the mother during the gestation period (Table 2). 


\section{Serious isolated MR cases}

In serious isolated MR, predictors of MR were advanced maternal age, low economic status, late birth cry, multiple births, neonatal jaundice and lack of breastfeeding. Risk factor, cohabitation with the male partner who drinks heavily was more likely associated with serious MR (Table 3).

\section{Serious MR cases with other neurological disorders}

These cases also showed similar associations as are seen in serious isolated cases except consanguinity which was found to be significantly associated and cohabitation with the male partner who drinks heavily was not proved to be a potent risk factor. Most of the cases were born at home. But in MR cases having other neurological disorders factors like paternal age, history of first trimester bleeding, consanguinity and high body temperature during pregnancy showed associations. Consanguinity was not observed in parents of MR cases with other neurological disorders (Table 3).

\section{DISCUSSIONS}

Mental retardation is one of the most difficult categories to document epidemiologically because causative reasons are obscure (Richmond et al., 1983). The present study examined the association of various risk factors with various subgroups of mental retardation in a sample of 150 patients. This study was focused on demographic, prenatal, prenatal and neonatal risk factors, which might be associated with less cognitive development.

A wide variety of mental health conditions like Down's syndrome, schizophrenia, autism spectrum disorders has been linked with biological parental age at conception (Bilder et al., 2009; Erik et al., 2012; Miller et al., 2011; Sandin et al., 2012; Sherman et al., 2007). Previously, it was believed that possibility of mental retardation is greater in the older mother as compared to the older father (Cohen, 2014; Croen et al., 2001; Hassold, and Hunt, 2009; Hidayat, 2017; Huang et al., 2016). But, present study is in sharp contrast to previous ones; both maternal and paternal age effect was found in mentally retarded individuals. Mild mental retardation was found to be associated with the father's age in isolated cases, but not in serious cases, but serious cases were found to be associated in an independent manner with maternal age. Our results are in line with many studies done so far (Drews et al., 1995; Lisa et al., 2001). It is well-known fact that heightened risks of mental retardation with advanced maternal age is due to errors which occur during chromosomal segregation (Hassold and Hunt, 2009). Conversely, emergent awareness also gives an indication about that advanced paternal age at childbearing is associated with offspring morbidity, including psychiatric disorders. A recent work suggested that increased de novo mutations in men's sperms as aging occurs may play important role in increasing rates of cognitive disability (Kong et al., 2012).

Previous studies suggested the difference in the effect of socio-economic status on an occurrence of mild and severe mental retardation (Emerson et al., 2006; Olson and Hwang, 2008; Muntaner et al.,2004), but the present study showed the dependence of this factor, over all subgroups of MR. The difference persisted in the occurrence of consanguinity in various subgroups of mental retardation, only serious MR cases were significantly associated and this information showed co linearity with many previous studies (Durkin et al., 1998). Cohabitation with the male partner who drinks heavily also found to be associated with various degrees of MR which is in contrast to information given by a study done by Durkin et al. in 2000. This is a well-known fact that immediate birth cry is needed for preventing brain damage due to asphyxia which can be the cause of many mental disorders in infants (Golubnitschaja et al., 2011). This risk factor was also found to be associated with various levels of MR. Like other investigators ((Boyle et al., 1997; Camp et al., 1998), 
we also found a significant association between multiple births and all subgroups of MR. Neonatal Jaundice proved to be a potent neonatal factor in mild and MR cases but no significant association was observed in serious cases. Neonatal jaundice was suggested to be a risk factor for brain damage in a study, done by Ullah et al. 2016. Most of the cases were born at home, which depicts that lack of medical facilities could also be the reason which might be associated with other factors like neonatal jaundice, neonatal breathing difficulties etc. Studies related to finding association between breast feeding and incidences of mental disorders are obscure, keeping this in mind we had also considered this factor to find the association and we observed that all degrees of MR were significantly associated with this factor. This information is in line with many previous studies (Anselmi et al., 2008; De Mola et al., 2016; Kramer et al., 2011; Kwok et al., 2013; Lind et al., 2014).Mental retardation (MR) has distressing effects on people and the health system so the salutogenic perspective of parents having mentally retarded children also needs to be compared with control group.

\section{CONCLUSIONS}

It is noteworthy that many risk factors showed associations only in isolated cases, which was the purpose of classifying samples in subgroups for controlling the effects of other neurological factors on MR. In this regard our study is unique moreover consistency with other reports also overweighs its dependability to its association with major risk factors and this information can help people in providing confirmation about pathogenesis, diagnosis, reappearance risk and appropriate medical intervention.

\section{REFERENCES}

1. AAMR (1992). American association on mental retardation: Diagnostic criteria from DSM-IV: Diagnostic and statistical manual of mental disorders, Washington DC: American Psychiatric Association, 63-66.

2. McLaren, J. \& Bryson, S.E. (1987). Review of recent epidemiological studies of mental retardation: prevalence, associated disorders and etiology. American Journal of Mental Retardation, 92, 243- 254.

3. Stevenson, R.E., Massey, P.S., Schroer, R.J., McDermott, S. \& Richter, B. (1996). Preventable fraction of mental retardation: analysis based on individuals with severe mental retardation. Mental Retardation, 34, 182-188.

4. Zeldin, A.S. \& Kao, A. (2012). Mental Retardation clinical presentation. Retrieved from http://emedicine.medscape.com /2012/ 7/article/1 180709.

5. Charara, R., Forouzanfar, M., Naghavi, M., Moradi-Lakeh, M., Vos, T. et al. (2017). The burden of Eastern Mediterranean Regions. Plos One, 12, e0169575.

6. Lakhan, R., Ekundayo, O.T. \& Shahbazi, M. (2015). An estimation of the prevalence of intellectual disabilities and its association with age in rural and urban populations in India. Journal of Neuroscience in Rural Practice, 6, 523-528.

7. Maulik, P. K., Mascarenhas, M.N., Mathers, C.D., Dua, T. \& Saxena, S. (2011). Prevalence of intellectual disability: a metaanalysis of population-based studies. Research on Developmental Disability, 32, 419-436.

8. McKenzie, K., Milton, M., Smith, G. \& Ouellette-Kuntz, H. (2016).Systematic review of the prevalence and incidence of intellectual disabilities: current trends and issues. Current Developmental Disorders Report, 3, 104-115.

9. Richmond, J.B., Butler, J.A. \& Stenmark S. (1983). Reducing childhood disability in the 80s. Hospital and Community Psychiatry, 34, 507-514.

10. Bilder, Deborah, Pinborough-Zimmerman, J., Miller, J. \& McMahon, W. (2009). Prenatal, perinatal, and neonatal factors associated with autism spectrum disorders. Pediatrics, 123, 1293-1300. 
11. Erik, P.T., Baron-Cohen, S., Lauritsen, M. B., Jorgensen, M., Schieve, L.A. et al. (2012). Parental age and autism spectrum disorders. Annals of Epidemiology, 22, 143-150.

12. Miller, Brian, Suvisaari, J., Miettunen,J., Marjo-Riitta Jarvelin \& Haukka, J.(2011). Advanced paternal age and parental history of schizophrenia. Schizophrenia Research, 133, 125-132.

13. Sandin, Sven, Hultman, C. M., Kolevzon, A., Gross, R., MacCabe, J.H. et al. (2012). Advancing maternal age is associated with increasing risk for autism: a review and meta-analysis. Journal of the American Academy of Child and Adolescent Psychiatry, 51, 477-486.

14. Sherman, Stephanie L., Allen, E.G., Bean, L.H. \& Freeman, S.B. (2007). Epidemiology of Down syndrome. Mental Retardation and Development Mental Disabilities Research Reviews, 13, 221-227.

15. Cohen, P. N. (2014). Parental Age and Cognitive Disability among Children in the United States. Sociological Science, 1 , $102-110$

16. Croen, L.A., Gether, J.K. \& Selvin, S. (2001). The epidemiology of mental retardation of unknown cause. Pediatrics, 10 , e86.

17. Hassold, T. \& Hunt, P. (2009). Maternal age and chromosomally abnormal pregnancies: What we know and what we wish we knew. Current Opinion Pediatrics, 21, 703-708.

18. Hidayat, H.J. (2017). Maternal age and consanguinity as risk factors for cerebral palsy combine mental retardation among Children in Erbil City/Kurdistan Region. A Special Issue for 4th International Conference of Cihan University-Erbil on Biological Sciences, 278-283.

19. Huang, J., Zhu, T., Qu, Y. \& Mu D. (2016). Prenatal, perinatal and neonatal risk factors for intellectual disability: A Systemic Review and Meta-Analysis. Plos One, 11, e0153655.

20. Drews, C., Yeargin-Alsopp, M., Decoufle, P.\& Murphy, C. (1995). Variation in the influence of selected sociodemographic risk factors for mental retardation. American Journal of Public Health, 85, 329-334.

21. Lisa, A.C., Judith, K., \& Grether, S.S. (2001). The epidemiology of mental retardation of unknown cause. Pediatrics, 107, 8692 ,

22. Kong, Augustine, Frigge, M.L., Masson, G., Besenbacher, S., Patrick Sulem, P. et al. 2012. Rate of de novo mutations and the importance offather's age to disease risk. Nature 488: 471-475.

23. Emerson, E., Hatton, C., Llewellyn, G., Blacher, J. \& Graham, H. (2006) Socioeconomic position, household composition, health status and indicators of the well-being of mothers of children with and without intellectual disabilities. Journal of Intellectual Disability Research, 50, 862-873.

24. Olsson, M.B. \& Hwang, C.P. (2008). Risk and protective factors for parental well-being. Journal of Intellectual Disability Research, 52, 1102-1113.

25. Muntaner, C., Eaton, W.W., Miech, $R \&$ \& $O$ 'Campo, P. (2004). Socioeconomic position and major mental disorders. Epidemiolocal Reviews, 26, 53-62.

26. Durkin, M.S., Hasan, Z.M. \& Hasan, K.Z. (1998). Prevalence and correlates of mental retardation among children in Karachi, Pakistan. American Journal of Epidemiology, 147, 281-288.

27. Durkin, M.S., Khan, N., Davidson, L.L., Huq, S., Munir, S., Rasul, E. \& Zaman, S.S. (2000). Prenatal and postnatal risk factors for mental retardation among children in Bangladesh. Amerian Journal of Epidemiology, 152, 1024-1033.

28. Golubnitschaja, O., Yeghiazaryan, K., Cebioglu, M. \& Micaela (2011). Birth asphyxia as the major complication in newborns: 
moving towards improved individual outcomes by prediction, targeted prevention and tailored medical care. European Association of predictive, preventive and personalized medicines, 2,197-210.

29. Boyle, C., Keddie, A. \& Holmgreen, P. (1997). The risk of mental retardation in twins. Society Pediatric Epidemiologic Research, 11, Al.

30. Camp, B.W., Broman, S.H., Nochols, P.L. \& Leff, M. (1998). Maternal and neonatal risk factors for mental retardation: defining the at risk child. Early Human Development, 50, 159-173.

31. Ullah, S., Rahman, K. \& Heydayati, M. (2016). Hyperbilirubinemia in Neonates: Types, Causes, Clinical Examinations, Preventive Measures and Treatments: A Narrative Review Article. Iranian Journal of Public Health, 45, 558-568.

32. Anselmi, L., Barros, F.C., Minten, G.C., Gigante, D.P., Horta, B.L. \& Victora, C.G. (2008). Prevalence and early determinants of common mental disorders in the 1982 birth cohort, Pelotas, Southern Brazil. Revista De Saude Publication, 42, 26-33.

33. De Mola, C.L., Horta, B. L., Gonçalves, H., de Avila Quevedo, L., Pinheiro, R C., Gigante, D.P., Motta, J. V. \& Barros, F. C. (2016). Breastfeeding and mental health in adulthood: A birth cohort study in Brazil. Journal of Affective Disorders, 202, $115-119$.

34. Kramer, M.S., Fombonne, E., Matush, L., Bogdanovich, N., Dahhou, M. \& Platt, R.W. (2011).Long-term behavioural consequences of infant feeding: the limits of observationalstudies.Paediatric and.Perinatal Epidemiology, 25, 500-506.

35. Kwok, M. K., Leung, G.M. \& Schooling, C.M. (2013).Breastfeeding and early adolescent behaviour, self-esteem and depression: Hong Kong's 'Children of1997' birth cohort. Archives of Disease in Childhood, 98, 887-894.

36. Lind, J.N., Li, R., Perrine, C.G. \& Schieve, L.A. (2014). Breast feeding and later psycho- social development of children at 6 years of age. Pediatrics 134, 36-41.

\section{APPENDICES}

Table 1: Percentage Distribution of Various Variables in Population Cohorts of Mentally Retarded and Normal Individuals

\begin{tabular}{|c|c|c|c|c|c|c|c|c|c|c|}
\hline Variables & & $\begin{array}{l}\text { Isola } \\
\text { (I }\end{array}$ & $\begin{array}{l}\text { d MR } \\
\text { :63) }\end{array}$ & & & $\begin{array}{r}\text { vith Otl } \\
\text { Con } \\
(\mathrm{N} \\
\end{array}$ & $\begin{array}{l}\text { r Neuro } \\
\text { itions } \\
87) \\
\end{array}$ & gical & & 50) \\
\hline $\begin{array}{c}\text { Demographic } \\
\text { Factors }\end{array}$ & $\mathbf{N}$ & $\%$ & $\begin{array}{c}X^{2} \\
\text { Value }\end{array}$ & Sig. & $\mathbf{N}$ & $\%$ & $\begin{array}{c}X^{2} \\
\text { Value }\end{array}$ & Sig. & $\mathbf{N}$ & $\%$ \\
\hline $\begin{array}{l}\text { 1.Paternal age } \\
\text { i. }<30 \\
\text { ii. } \geq 30\end{array}$ & $\begin{array}{l}45 \\
18\end{array}$ & $\begin{array}{l}71.43 \\
28.57\end{array}$ & 5.00 & 0.025 & $\begin{array}{l}61 \\
26\end{array}$ & $\begin{array}{l}70.11 \\
29.89\end{array}$ & 7.11 & 0.008 & $\begin{array}{c}127 \\
23\end{array}$ & $\begin{array}{l}84.67 \\
15.33\end{array}$ \\
\hline $\begin{array}{l}\text { 2. Maternal age } \\
\text { i. }<30 \\
\text { ii. } \geq 30\end{array}$ & $\begin{array}{l}48 \\
15\end{array}$ & $\begin{array}{l}76.19 \\
23.81\end{array}$ & 5.41 & 0.02 & $\begin{array}{l}71 \\
16\end{array}$ & $\begin{array}{l}81.60 \\
18.40\end{array}$ & 2.29 & 0.13 & $\begin{array}{c}133 \\
17\end{array}$ & $\begin{array}{l}88.67 \\
11.33\end{array}$ \\
\hline $\begin{array}{l}\text { 3.Economic } \\
\text { status } \\
\text { i. Low } \\
\text { ii. Middle } \\
\text { iii. High }\end{array}$ & $\begin{array}{l}36 \\
13 \\
14\end{array}$ & $\begin{array}{l}57.15 \\
20.63 \\
22.22\end{array}$ & 37.12 & $<0.001$ & $\begin{array}{c}49 \\
2117\end{array}$ & $\begin{array}{l}56.32 \\
24.14 \\
19.54\end{array}$ & 42.00 & $<0.001$ & $\begin{array}{c}24 \\
118 \\
8\end{array}$ & $\begin{array}{c}16.00 \\
78.67 \\
5.33\end{array}$ \\
\hline
\end{tabular}




\begin{tabular}{|c|c|c|c|c|c|c|c|c|c|c|}
\hline \multicolumn{11}{|c|}{ Table 1: contd., } \\
\hline $\begin{array}{l}\text { Prenatal } \\
\text { Factors }\end{array}$ & & & & & & & & & & \\
\hline 1.Consanguinity & 1 & 1.58 & 2.39 & $0.30^{*}$ & 2 & 2.29 & 3.48 & $0.13 *$ & 0 & 0.00 \\
\hline $\begin{array}{l}\text { 2. History of first } \\
\text { trimester } \\
\text { Bleeding }\end{array}$ & 10 & 15.87 & 1.12 & 0.30 & 18 & 20.69 & 4.50 & 0.03 & 16 & 10.67 \\
\hline $\begin{array}{l}\text { 3. High body } \\
\text { temperature } \\
\text { during } \\
\text { pregnancy }\end{array}$ & 9 & 14.28 & 1.97 & 0.16 & 16 & 18.39 & 6.06 & 0.01 & 12 & 8.00 \\
\hline $\begin{array}{l}\text { 4. Maternal } \\
\text { anemia }\end{array}$ & 6 & 9.52 & 0.84 & 0.36 & 7 & 8.04 & 0.37 & 0.54 & 9 & 6.00 \\
\hline $\begin{array}{l}\text { 5. Maternal } \\
\text { diabetes }\end{array}$ & 2 & 3.17 & 2.01 & $0.21 *$ & 4 & 4.60 & 4.12 & $0.06^{*}$ & 1 & 0.67 \\
\hline $\begin{array}{l}\text { 6. Cohabitation } \\
\text { with male } \\
\text { partner who } \\
\text { drinks heavily }\end{array}$ & 17 & 26.98 & 6.20 & 0.01 & 24 & 27.59 & 11.24 & 0.001 & 16 & 10.67 \\
\hline \multicolumn{11}{|l|}{$\begin{array}{l}\text { Perinatal } \\
\text { factors }\end{array}$} \\
\hline $\begin{array}{l}\text { 1. Late Birth cry } \\
<5 \text { minutes } \\
\geq 5 \text { minutes }\end{array}$ & $\begin{array}{l}9 \\
5\end{array}$ & $\begin{array}{c}14.28 \\
7.94\end{array}$ & 15.20 & $<0.001$ & $\begin{array}{c}18 \\
6\end{array}$ & $\begin{array}{c}20.69 \\
6.90\end{array}$ & 26.7 & $<0.001$ & $\begin{array}{l}2 \\
0\end{array}$ & $\begin{array}{l}1.33 \\
0.00\end{array}$ \\
\hline 2. Multiple birth & 14 & 22.22 & 31.49 & $<0.001$ & 19 & 21.84 & 31.94 & $<0.001$ & 1 & 0.67 \\
\hline 3. Born at home & 41 & 65.08 & 4.82 & 0.03 & 59 & 67.82 & 3.91 & 0.05 & 119 & 79.33 \\
\hline \multicolumn{11}{|l|}{$\begin{array}{l}\text { Neonatal } \\
\text { factors }\end{array}$} \\
\hline $\begin{array}{l}\text { 1.Neonatal } \\
\text { jaundice }\end{array}$ & 9 & 14.28 & 18.39 & $<0.001$ & 20 & 22.99 & 33.97 & $<0.001$ & 1 & 0.67 \\
\hline $\begin{array}{l}\text { 2.Neonatal } \\
\text { breathing } \\
\text { difficulty }\end{array}$ & 4 & 6.35 & 1.66 & $0.24 *$ & 6 & 6.90 & 2.44 & $0.18^{*}$ & 4 & 2.67 \\
\hline $\begin{array}{l}\text { 3. Lack of breast } \\
\text { feeding }\end{array}$ & 27 & 42.86 & 54.29 & $<0.001$ & 38 & 43.68 & 60.35 & $<0.001$ & 5 & 3.33 \\
\hline
\end{tabular}

Table 2: Association of Mild MR with Various Risk Factors in Isolated and Cases

With Other Neurological Disorders

\begin{tabular}{|c|c|c|c|c|c|c|c|c|c|c|}
\hline \multirow{2}{*}{$\begin{array}{c}\text { Variables } \\
\begin{array}{c}\text { Demographic } \\
\text { Factors }\end{array} \\
\end{array}$} & \multicolumn{4}{|c|}{$\begin{array}{c}\text { Isolated Mild MR } \\
(\mathbf{N}=\mathbf{5 3})\end{array}$} & \multicolumn{4}{|c|}{$\begin{array}{l}\text { Mild MR with Other } \\
\text { Neurological Conditions } \\
(\mathrm{N}=62)\end{array}$} & \multicolumn{2}{|c|}{$\begin{array}{l}\text { Control } \\
(\mathrm{N}=150)\end{array}$} \\
\hline & $\mathbf{N}$ & $\%$ & $\begin{array}{c}X^{2} \\
\text { Value }\end{array}$ & Sig. & $\mathbf{N}$ & $\%$ & $\begin{array}{c}X^{2} \\
\text { Value }\end{array}$ & Sig. & $\mathbf{N}$ & $\%$ \\
\hline $\begin{array}{l}\text { 1.Paternal age } \\
\text { i. }<30 \\
\text { ii. } \geq 30\end{array}$ & $\begin{array}{l}37 \\
16\end{array}$ & $\begin{array}{c}69.8 \\
1 \\
30.1 \\
9\end{array}$ & 5.57 & 0.02 & $\begin{array}{l}42 \\
20\end{array}$ & $\begin{array}{l}67.74 \\
32.26\end{array}$ & 7.77 & 0.005 & $\begin{array}{c}127 \\
23\end{array}$ & $\begin{array}{l}84.67 \\
15.33\end{array}$ \\
\hline $\begin{array}{l}\text { 2.Maternal age } \\
\text { i. }<30 \\
\text { ii. } \geq 30\end{array}$ & $\begin{array}{c}45 \\
8\end{array}$ & $\begin{array}{c}84.9 \\
0 \\
15.0 \\
9\end{array}$ & 0.51 & 0.47 & $\begin{array}{c}61 \\
1\end{array}$ & $\begin{array}{c}98.39 \\
1.61\end{array}$ & 5.33 & $0.03 *$ & $\begin{array}{c}133 \\
17\end{array}$ & $\begin{array}{l}88.67 \\
11.33\end{array}$ \\
\hline
\end{tabular}




\begin{tabular}{|c|c|c|c|c|c|c|c|c|c|c|}
\hline \multicolumn{11}{|c|}{ Table 2: contd., } \\
\hline $\begin{array}{l}\text { 3.Economic } \\
\text { status } \\
\text { i. Low } \\
\text { ii. Middle } \\
\text { iii. High }\end{array}$ & $\begin{array}{l}31 \\
10 \\
14\end{array}$ & $\begin{array}{c}58.4 \\
9 \\
18.8 \\
7 \\
26.4 \\
1\end{array}$ & 39.31 & $\begin{array}{c}<0.00 \\
1\end{array}$ & $\begin{array}{l}33 \\
15 \\
14\end{array}$ & $\begin{array}{l}53.22 \\
24.19 \\
22.59\end{array}$ & 34.21 & $<0.001$ & $\begin{array}{c}24 \\
118 \\
8\end{array}$ & $\begin{array}{c}16.00 \\
78.67 \\
5.33\end{array}$ \\
\hline \multicolumn{11}{|l|}{$\begin{array}{l}\text { Prenatal } \\
\text { Factors }\end{array}$} \\
\hline $\begin{array}{l}\text { 1.Consanguinit } \\
\text { y }\end{array}$ & 0 & 0.00 & NA & NA & 0 & 0.00 & NA & NA & 0 & 0.00 \\
\hline $\begin{array}{l}\text { 2. History of } \\
\text { first trimester } \\
\text { Bleeding }\end{array}$ & 8 & $\begin{array}{c}15.0 \\
9\end{array}$ & 0.74 & 0.39 & 15 & 24.19 & 6.43 & 0.01 & 16 & 10.67 \\
\hline $\begin{array}{l}\text { 3. High body } \\
\text { temperature } \\
\text { during } \\
\text { pregnancy }\end{array}$ & 7 & $\begin{array}{c}13.2 \\
1\end{array}$ & 1.25 & 0.26 & 13 & 20.97 & 7.09 & 0.008 & 12 & 8.00 \\
\hline $\begin{array}{l}\text { 4. Maternal } \\
\text { anemia }\end{array}$ & 5 & 9.43 & 0.72 & 0.40 & 4 & 6.45 & 0.02 & $0.90^{*}$ & 9 & 6.00 \\
\hline $\begin{array}{l}\text { 5. Maternal } \\
\text { diabetes }\end{array}$ & 2 & 3.77 & 2.60 & $0.17 *$ & 3 & 4.83 & 4.12 & $0.08^{*}$ & 1 & 0.67 \\
\hline $\begin{array}{l}6 . \\
\text { Cohabitation } \\
\text { with male } \\
\text { partner who } \\
\text { drinks heavily }\end{array}$ & 13 & $\begin{array}{c}24.5 \\
3\end{array}$ & 6.14 & 0.01 & 21 & 33.87 & 16.40 & $<0.001$ & 16 & 10.67 \\
\hline \multicolumn{11}{|l|}{$\begin{array}{l}\text { Perinatal } \\
\text { factors }\end{array}$} \\
\hline $\begin{array}{l}\text { 1. Late Birth } \\
\text { cry } \\
<5 \text { minutes } \\
\geq 5 \text { minutes }\end{array}$ & $\begin{array}{l}7 \\
4\end{array}$ & $\begin{array}{c}13.2 \\
0 \\
7.54\end{array}$ & 13.03 & $\begin{array}{c}0.001 \\
*\end{array}$ & $\begin{array}{c}12 \\
4\end{array}$ & $\begin{array}{l}19.35 \\
6.45\end{array}$ & 23.10 & $<0.001$ & $\begin{array}{l}2 \\
0\end{array}$ & $\begin{array}{l}1.33 \\
0.00\end{array}$ \\
\hline $\begin{array}{l}\text { 2. Multiple } \\
\text { birth }\end{array}$ & 9 & $\begin{array}{c}16.9 \\
8\end{array}$ & 22.56 & $\begin{array}{c}<0.00 \\
1\end{array}$ & 13 & 20.97 & 29.31 & $<0.001$ & 1 & 0.67 \\
\hline $\begin{array}{l}\text { 3. Born at } \\
\text { home }\end{array}$ & 31 & $\begin{array}{c}58.4 \\
9\end{array}$ & 8.82 & 0.003 & 39 & 62.90 & 6.24 & 0.01 & 119 & 79.33 \\
\hline \multicolumn{11}{|l|}{$\begin{array}{l}\text { Neonatal } \\
\text { factors }\end{array}$} \\
\hline $\begin{array}{l}\text { 1.Neonatal } \\
\text { jaundice }\end{array}$ & 1 & 1.89 & 0.60 & $0.46^{*}$ & 3 & 4.84 & 4.12 & $0.08^{*}$ & 1 & 6.67 \\
\hline $\begin{array}{l}\text { 2.Neonatal } \\
\text { breathing } \\
\text { difficulty }\end{array}$ & 2 & 3.77 & 0.17 & $0.65 *$ & 4 & 6.45 & 1.73 & $0.24^{*}$ & 4 & 2.67 \\
\hline $\begin{array}{l}\text { 3. Lack of } \\
\text { breast feeding }\end{array}$ & 18 & $\begin{array}{c}33.9 \\
6\end{array}$ & 36.57 & $\begin{array}{c}<0.00 \\
1\end{array}$ & 27 & 43.54 & 55.36 & $<0.001$ & 5 & 3.33 \\
\hline
\end{tabular}



in the Population of Himachal Pradesh, India

Table 3: Percent Distribution of Various Risk Factors and Their Association with Serious Mental Retardation

\begin{tabular}{|c|c|c|c|c|c|c|c|c|c|c|}
\hline \multirow{2}{*}{\begin{tabular}{|c|} 
Variables \\
$\begin{array}{c}\text { Demographic } \\
\text { Factors }\end{array}$
\end{tabular}} & \multicolumn{4}{|c|}{$\begin{array}{l}\text { Isolated Serious MR } \\
\qquad(\mathbf{N}=10)\end{array}$} & \multicolumn{4}{|c|}{$\begin{array}{l}\text { Serious MR with Other } \\
\text { Neurological Conditions } \\
(\mathrm{N}=25)\end{array}$} & \multicolumn{2}{|c|}{$\begin{array}{l}\text { Control } \\
(\mathbf{N}=150)\end{array}$} \\
\hline & $\mathbf{N}$ & $\%$ & $\begin{array}{c}X^{2} \\
\text { Value }\end{array}$ & Sig. & $\mathbf{N}$ & $\%$ & $\begin{array}{c}\mathrm{X}^{2} \\
\text { Value }\end{array}$ & Sig. & $\mathbf{N}$ & $\%$ \\
\hline $\begin{array}{l}\text { 1.Paternal age } \\
\text { i. }<30 \\
\text { ii. } \geq 30\end{array}$ & $\begin{array}{l}8 \\
2\end{array}$ & $\begin{array}{l}80.00 \\
20.00\end{array}$ & 0.15 & 0.69 & $\begin{array}{c}19 \\
6\end{array}$ & $\begin{array}{l}76.00 \\
24.00\end{array}$ & 1.16 & 0.28 & $\begin{array}{c}127 \\
23\end{array}$ & $\begin{array}{l}84.67 \\
15.33\end{array}$ \\
\hline $\begin{array}{l}\text { 2.Maternal age } \\
\text { i. }<30 \\
\text { ii. } \geq 30\end{array}$ & $\begin{array}{l}3 \\
7\end{array}$ & $\begin{array}{l}30.00 \\
70.00\end{array}$ & 25.31 & $<0.001$ & $\begin{array}{l}10 \\
15\end{array}$ & $\begin{array}{l}40.00 \\
60.00 \\
\end{array}$ & 33.97 & $<0.001$ & $\begin{array}{c}133 \\
17\end{array}$ & $\begin{array}{l}88.67 \\
11.33 \\
\end{array}$ \\
\hline $\begin{array}{l}\text { 3.Economic status } \\
\text { i. Low } \\
\text { ii. Middle } \\
\text { iii. High }\end{array}$ & $\begin{array}{l}5 \\
3 \\
2\end{array}$ & $\begin{array}{l}50.00 \\
30.00 \\
20.00\end{array}$ & 7.30 & 0.007 & $\begin{array}{c}16 \\
6 \\
3\end{array}$ & $\begin{array}{l}64.00 \\
24.00 \\
12.00\end{array}$ & 28.00 & $<0.001$ & $\begin{array}{c}24 \\
118 \\
8\end{array}$ & $\begin{array}{c}16.00 \\
78.67 \\
5.33\end{array}$ \\
\hline \multicolumn{11}{|l|}{$\begin{array}{l}\text { Prenatal } \\
\text { Factors } \\
\end{array}$} \\
\hline 1.Consanguinity & 1 & 10.00 & 15.09 & $0.06^{*}$ & 2 & 8.00 & 12.14 & $0.02 *$ & 0 & 0.00 \\
\hline $\begin{array}{l}\text { 2. History of first } \\
\text { trimester } \\
\text { Bleeding }\end{array}$ & 2 & 20.00 & 0.82 & $0.37 *$ & 3 & 12.00 & 0.04 & $0.74 *$ & 16 & 10.67 \\
\hline $\begin{array}{l}\text { 3. High body } \\
\text { temperature } \\
\text { during pregnancy }\end{array}$ & 2 & 20.00 & 1.69 & $0.21 *$ & 3 & 12.00 & 0.44 & $0.45 *$ & 12 & 8.00 \\
\hline $\begin{array}{l}\text { 4. Maternal } \\
\text { anaemia }\end{array}$ & 1 & 10.00 & 0.26 & $0.49 *$ & 3 & 12.00 & 1.21 & $0.38 *$ & 9 & 6.00 \\
\hline $\begin{array}{l}\text { 5. Maternal } \\
\text { diabetes }\end{array}$ & 0 & 0.00 & 0.07 & $0.80 *$ & 1 & 4.00 & 2.11 & $0.27 *$ & 1 & 0.67 \\
\hline $\begin{array}{l}\text { 6. Cohabitation } \\
\text { with male partner } \\
\text { who drinks } \\
\text { heavily }\end{array}$ & 4 & 40.00 & 7.38 & $0.02 *$ & 3 & 12.00 & 0.04 & $0.74 *$ & 16 & 10.67 \\
\hline \multicolumn{11}{|l|}{ Perinatal factors } \\
\hline $\begin{array}{l}\text { 1. Late Birth cry } \\
<5 \text { minutes } \\
\geq 5 \text { minutes }\end{array}$ & $\begin{array}{l}2 \\
1\end{array}$ & $\begin{array}{l}20.00 \\
10.00\end{array}$ & $\begin{array}{l}13.40 \\
15.09\end{array}$ & $0.02 *$ & $\begin{array}{l}6 \\
2\end{array}$ & $\begin{array}{c}24.00 \\
8.00\end{array}$ & $\begin{array}{l}25.24 \\
12.14\end{array}$ & $<0.001$ & $\begin{array}{l}2 \\
0\end{array}$ & $\begin{array}{l}1.33 \\
0.00\end{array}$ \\
\hline 2. Multiple birth & 5 & 50.00 & 63.22 & $<0.001$ & 6 & 24.00 & 30.38 & $<0.001$ & 1 & 0.67 \\
\hline 3. Born at home & 10 & 10.00 & 2.56 & 0.11 & 20 & 80.00 & 0.006 & 0.94 & 119 & 79.33 \\
\hline \multicolumn{11}{|l|}{ Neonatal factors } \\
\hline $\begin{array}{l}\text { 1.Neonatal } \\
\text { jaundice }\end{array}$ & 8 & 80.00 & 111.1 & $<0.001$ & 17 & 68.00 & 105.3 & $<0.001$ & 1 & 0.67 \\
\hline $\begin{array}{l}\text { 2.Neonatal } \\
\text { breathing } \\
\text { difficulty }\end{array}$ & 2 & 20.00 & 7.80 & $0.05 *$ & 2 & 8.00 & 1.84 & 0.20 & 4 & 2.67 \\
\hline $\begin{array}{l}\text { 3. Lack of breast } \\
\text { feeding }\end{array}$ & 9 & 90.00 & 88.19 & $<0.001$ & 11 & 44.00 & 42.66 & $<0.001$ & 5 & 3.33 \\
\hline
\end{tabular}

- Use of superscript* in some $\chi 2$-values indicates that these $\chi 2$-values are computed using Fischer's exact test modification of $\chi 2$ test due to small sample sizes. 
